\title{
Geçiş Ekonomilerinde Kurumsal Sosyal Sorumluluk, Ahlaki Bozulma ve İçsel Motivasyon Arasındaki İlişkiler
}

\author{
Erkin CHARYYEV*, Canan Nur KARABEY**
}

öz

\begin{abstract}
$\mathrm{Bu}$ çalışmanın amacı, geçiş ekonomilerinde çalışanların kurumsal sosyal sorumluluk algısını, iş hayatında ahlaki bozulma algısını ve içsel motivasyon düzeylerini incelemek, ahlaki bozulma ve sosyal sorumluluk algılarının içsel motivasyonları üzerinde etkili olup olmadığını belirlemektir. Çalışanların ahlaki bozulma algısının kurumsal sosyal sorumluluk ile içsel motivasyon düzeyi arasındaki ilişkide biçimlendirici (düzenleyici) rolünün bulunup bulunmadığı da araştırılmaktadır. Araştırmanın ana kütlesini Türkmenistan'ın Türkmenabat şehrinde bulunan bir devlet hastanesinde faaliyet gösteren 193 çalışan oluşturmaktadır. Bu ana kütleden $\% 95$ güven düzeyinde $\% 5$ hata payı ile seçilen 129 çalışan araştırmanın örneklemini oluşturmaktadır. Yeterli örneklem büyüklüğüne ulaşmak amacıyla basit tesadüfi örnekleme yöntemiyle toplam 140 kişiye anket uygulanmış ve veriler toplanmıştır. Soru formlarıyla toplanan veriler IBM SPSS 25 programı ile analiz edilmiştir. Yapılan analizlerle çalışanın kurumsal sosyal sorumluluk algısı arttıç̧a içsel motivasyonunun arttı̆̆ bulunmuştur. Ayrıca çalışanların ahlaki bozulma algısı arttıkça kurumsal sosyal sorumluluk ile içsel motivasyon düzeyi arasındaki ilişkinin güçlendiği tespit edilmiştir.
\end{abstract}

Anahtar Kelimeler: Kurumsal Sosyal Sorumluluk, Ahlaki Bozulma, İçsel Motivasyon

JEL Sinıflandırması: M10

\section{The Relationships among Corporate Social Responsibility, Moral Degradation and Intrinsic Motivation in Transition Economies}

\begin{abstract}
The aim of this study is to examine corporate social responsibility perception, moral degradation perception and intrinsic motivation of employees in transition economies and to determine whether perceptions of social responsibility and moral degradation have an impact on intrinsic motivation. It is also investigated whether moral degradation perception in business life has a moderating effect in the relationship between corporate social responsibility and intrinsic motivation. The population of the study consist of 193 employees of a public hospital in Turkmenabat. 140 people were selected using simple random sampling method. Data were collected through question forms and analyzed with IBM SPSS 25 . It was found that the higher the corporate social responsibility perception the higher intrinsic motivation. It was also found that the higher moral degradation perception, the lower intrinsic motivation. Besides, as the moral degradation perception strengthens, the positive impact of social responsibility on intrinsic motivation strengthens as well.
\end{abstract}

Keywords: Corporate Social Responsibility, Moral Degradation, Intrinsic Motivation

JEL Classification: M10

Geliş Tarihi / Received: 12.07.2021 Kabul Tarihi / Accepted: 13.10.2021 Doi: 10.17541/optimum.968922

\footnotetext{
*Bilim Uzman1, Atatürk Üniversitesi, SBE, turkmenabatt@ gmail.com, ORCID: 0000-0002-0873-7491

** Prof. Dr., Atatürk Üniversitesi, İ̈BF, İşletme Bölümü, ckarabey@atauni.edu.tr, ORCID: 0000-0003-0597-3605
} 


\section{GİRIŞ}

Ülkeleri birbirinden ayıran sınırların gün geçtikçe öneminin azalması ve teknolojik gelişmeler sayesinde çeşitli değerlerin dünya üzerinde yayılması gibi etkilerle ortaya çıkan küreselleşme olgusu, işletmeler arasında büyük bir rekabete yol açmıştır. Doğal kaynakların bilinçsizce tüketildiği, bilginin hızla eskidiği, işletmelerin sahip olduğu ekonomik, siyasi ve sosyal gücün arttığı günümüzde toplumun işletmelerden beklentileri de artmıştır. Bu beklentilere karşıllık gelen kurumsal sosyal sorumluluk (KSS) olgusu işletme çalışanlarının tutum ve davranışları üzerinde büyük bir öneme sahiptir. Kurumsal sosyal sorumluluk, bir örgütün topluma ve çevreye kural ve yasaların gereklilikleri konusunda katkıda bulunma amaçlı gönüllü girişim ve çabalarını içerir. Ayrıca kurumsal sosyal sorumluluk işletmelerin kâr amacı gütmekten ziyade topluma fayda sağlama yükümlülüğüne sahip olmalarına işaret etmektedir.

Ekonomik ilerlemelerin kaydedildiği ve rekabetin arttı̆g günümüzde, hayatta kalmak ve rekabetçi güçlerle baş edebilmek için işletmeler sürekli yeni çareler aramaktadır. İşletmeleri bu zorlayıcı ortamda başarıya taşıyan unsurlardan biri de yüksek motivasyon sahibi çalışanlardır. Ayrıca günümüzde çalışanların içsel motivasyonları onların iş hayatındaki başarılarını belirleyen temel unsurlardan biri olmaya başlamıştır. İçsel motivasyon bazı elde edilebilir somut sonuçlardan ziyade, içsel tatmin, yani zevk ve anlam duygusu için bir faaliyetin gerçekleştirilmesidir. İçsel olarak motive edilen bir kişi dış baskılar veya ödüller yüzünden değil, eğlenmek ya da zevk almak için harekete geçmektedir. Bu sebeple çalışanlarının içsel motivasyon düzeylerini etkileyen unsurları anlamak işletmeler için önemli bir hedeftir.

Olumlu davranışlara işaret eden pek çok evrensel ahlaki ilke bulunmasına karşın, insanların ahlaki olmayan davranışlarının nasıl açıklanacağı konusunda farklı görüşler mevcuttur. Ahlaki bozulma, bir toplumun sosyal geleneklerinde hüküm süren ahlaki ve etik standartların zayıflatılmasını ifade etmektedir. Diğer bir deyişle ahlaki bozulma, son derece yüksek sosyal adaletsizlik ve adaletsiz toplumsal koşullardan kaynaklanan zenginlik ile birlikte sosyal yönden hasta ve etik açıdan ilgisiz bir toplum yaratmaktadır. Çalışanların ekonomik işleyiş̧e ilişkin ahlaki bozulma algısının onların işyerindeki performanslarını da yönlendirecek şekilde pek çok tutum ve davranışlarını etkilemesi beklenir.

Bu çalışmada çalışanların kurumsal sosyal sorumluluk algısı, ahlaki bozulma algısı ve içsel motivasyon düzeyleri arasındaki ilişkiler incelenmiştir. KSS uygulamaları ile çalışanların içsel motivasyonları arasındaki ilişkiyi ortaya koymayı amaçlayan bu araştırmanın literatürdeki önemli bir boşluğu doldurması ve içsel motivasyon olgusunun daha iyi anlaşılmasına katkıda bulunması beklenmektedir. Ayrıca iş hayatında etik ihlallerin giderek daha fazla gözlendiği gerçeğinden hareketle, kurumsal sosyal sorumluluk faaliyetlerinin içsel motivasyona etkisinde çalışanların ahlaki bozulma algısının biçimlendirici bir rolü olup olmadığını belirlemek de konunun daha iyi anlaşılmasını sağlayabilir. Geçiş ekonomisi özelliği gösteren bir ülke olan Türkmenistan'da anket tekniğinden yararlanılarak yapılan alan araştırması ile çalışanların içsel motivasyonlarını artırmada kurumsal sosyal sorumluluk faaliyetlerinin bir etkisinin olup olmadığ 1 ve ahlaki bozulma algısının içsel motivasyona etkisi daha iyi anlaşılacaktır. Bilindiği gibi geçiş ekonomisi, devlet güdümlü ekonomiden serbest piyasa ekonomisine geçiş yapmakta olan ekonomilere verilen teknik bir isimdir. Geçiş ekonomisi kavramsal olarak devletin kontrolü altında bulunan ve genellikle orta vadeli planlı bir ekonomiden, liberalleşmenin piyasaları işgali ile birlikte serbest piyasa ekonomisine geçiş sürecini ifade eder. Bu kavram Orta Asya, Doğu Avrupa, Baltık ve Doğu Asya ülkelerini kapsayacak biçimde 1980'li yılların sonundan itibaren kullanılmaya başlanmıştır. Bu ülkelerin dönüşüm sürecinin temelinde planlı ekonominin yerine özel teşebbüsün hâkim olduğu bir sisteme geçiş yatmaktadır (Yurdadoğ vd., 2016: 102'den aktaran Eyidiker, 2020: 15). Geçiş ekonomisi özelliği gösteren ülkeler ekonomik liberalleşme sürecinde merkezi bir organizasyon yerine serbest piyasanın fiyatları belirlediği bir ortama geçiş yapmaktadır. Bu durum bu ülkelerdeki işletmelerin iş çevresine ilişkin algılarını, rekabetçi 
güçlerini ve yönetim anlayışlarını derinden etkilemektedir. Büyük bir değişim sürecinden geçen bu tür ülkelerde ekonomik, sosyal ve siyasi sistemlerdeki yetersizlikler sebebiyle iş hayatında yasa dışı ve/veya etik dışı faaliyetlere yönelme eğilimi oldukça güçlüdür. Dolayısıyla Türkmenistan örneğinden toplanan verilerle yürütülen bu çalışmanın ele aldığg değişkenler arasındaki ilişkileri aydınlatmaya katkıda bulunması hedeflenmektedir.

\section{KURAMSAL ÇERÇEVE}

Bu çalışmada ele alınan ilk değişken kurumsal sosyal sorumluluktur. Geniş bağlamda ele alınırsa KSS küresel şirketler, ülke hükümetleri ve vatandaşlar arasındaki ilişkinin ne olduğu veya ne olması gerektiği ile ilgilidir. Daha dar bir bakış açısıyla bakıldığında ise şirketin içinde bulunduğu veya faaliyet gösterdiği yerel toplum ile arasındaki ilişkiyle ilgilidir (Crowther ve Capaldi, 2008: 22). KSS bir örgütün topluma ve çevreye kural ve yasaların gereklilikleri konusunda katkıda bulunma amaçlı gönüllü girişim ve çabalarını içerir (Huang ve Watson, 2015'ten aktaran Tiggeman, 2018: 1). Üzerinde pek çok tartışma yapılan KSS kavramı işletmelerin kâr amacı gütmekten ziyade topluma fayda sağlama yükümlülügüne sahip olmalarına işaret eden bir olgu olarak ele alınmıştır (Hopkins, 2007: 28). KSS işletmelerin veya kuruluşların sahip olduğu ekonomik, yasal, etik ve gönüllülük esaslı beklentileri karşılamasıdır. $\mathrm{Bu}$ tanımda belirtilen ve birbirleriyle bağlantılı olan sorumluluk kategorilerini Caroll (1979) piramit şeklinde geliştirdiği model ile açıklamıştır. Piramit alttan yukarıya doğru ekonomik sorumluluk, yasal sorumluluk, etik sorumluluk ve gönüllü sorumluluk şeklinde sıralanmıştır (Aupperle, Carroll ve Hatfield, 1985'ten aktaran Nanderam, 2010: 20). İşletmelerin birinci ve en önemli sorumluluğu işin doğası gereği ekonomik sorumluluğudur. Caroll (1979)'a göre ekonomik sorumluluk pay sahipleri için değer yaratmak, çalışanlar için daha verimli çalışma koşulları ve daha çok istihdam olanakları sağlamak, toplum için iyi ve kaliteli ürünler üretmek, yenilikçi alanlar tanımlamak, yeni kaynakları araştırmak ve teknolojik unsurları geliştirmektir (Lantos, 2002; Caroll, 2004; Jamali ve Mirshak, 2007'den aktaran Çalışkan ve Ünsan, 2011: 157). Yasal sorumluluk, işletmelerin ekonomik faaliyetlerini sürdürürken bazı yasal kuralları göz önünde bulundurmasını ifade etmektedir. Yasa, kodlanmış etik olarak da düşünülebilir. Örgütün faaliyetlerinin yasa, kural ve düzenlemelere uygunluk düzeyi yasal boyutun içeriğini oluşturmaktadır. Etik sorumluluk, toplumun geleneksel, sosyal ve siyasi, ekonomik ve kültürel refahına zarar vermeden örgütlerin amaçlarına ulaşması için sergiledikleri ve izledikleri davranış türlerini ve etik normları temsil eder. Bu sorumluluk örgütün faaliyetlerinden doğabilecek toplumsal zararı önlemeye yöneliktir ve yasaların gerektirdiğinin ötesindeki eylemlere, kararlara ve uygulamalara kadar uzanır. Son olarak, piramidin tepesinde isteğe bağlı veya gönüllü sorumluluk vardır ve bu sorumluluk türü hiçbir karşılık beklenmeden yapılan faaliyetleri belirtir. $\mathrm{Bu}$ nedenle örgütlerin gönüllü sorumluluk faaliyetlerini uygularken esas amacı kendisine fayda sağlamaktan ziyade, bağlı olduğu sosyal çevreye veya topluma fayda sağlamaktır. Gönüllü sorumluluk, toplum için açık bir beklenti oluşturmayan gönüllülük esaslı rolleri, girişimleri ve uygulamaları içerir. $\mathrm{Bu}$ tür sorumluluğa işletmelerin hayırseverlik esaslı uygulamaları, çalışanların gönüllülük esaslı davranışları, kâr amacı gütmeyen örgütlere desteği ve çeşitli paydaş grupları ile daha iyi ilişkiler geliştirmeye yönelik diğer girişimler örnek verilebilir (Visser, Matten, Pohl ve Tolhurst, 2010: 108).

Çalışmanın ikinci değişkeni olan ahlaki bozulma Luo (2008)'ya göre bir toplumun sosyal geleneklerinde hüküm süren ahlaki ve etik standartların zayıflatılmasını ifade etmektedir. Ahlaki bozulmadan mustarip bir toplumdaki insanlar ahlak dışı davranışları ve algıları hoş görme, kabul etme ve hatta normalleştirme eğilimindedir. Martin vd. (2007) ahlaki açıdan yozlaşmış bir yerel ortamın rüşvet gibi yasadışı faaliyetleri artırdığını ortaya koymuştur. Ahlaki bozulma, son derece yüksek sosyal adaletsizlik ve adaletsiz toplumsal koşullardan kaynaklanan zenginlik ile birlikte sosyal yönden hasta ve etik açıdan ilgisiz bir toplum yaratmaktadır. Ayrıca 
ahlaki bozulma, bir toplumun örf ve adetleri üzerinde çok daha kalıcı ve kapsamlı etki oluşturmaktadır. Ahlaki bozulma kurumsal anomiye yol açmaktadır. North (1990)'a göre işletmeler politik ve ekonomik kurallar gibi resmi unsurları ve resmi olmayan sosyal norm ve sözleşmeleri içermektedir. Buna göre ahlaki bozulma yalnızca resmî kurumların gücünü zayıflatmakla kalmaz, aynı zamanda kayıt dışı kurumsal ideolojiyi de bozar. Merton (1968)'a göre ahlaki bozulma, davranışı yöneten kuralların güçlerini yitirdiği anormallik ve sosyal dengesizlik durumudur. Messner ve Rosenfeld (2001) ahlaki bozulmaya maruz kalan toplumlarda herhangi bir ekonomik sonuca ulaşma baskısının normatif kontrol mekanizmalarının yerini alacağını belirtmiştir. Durkheim (1966) modernleşmeyle ilişkili resmi olmayan kurumsal değişikliklerin geleneksel normları zayıflattığını, kültürel sapma ve demoralizasyonu artırdığını öne sürmektedir (Zheng, Lou ve Lu Wang, 2014: 206).

Çalışmanın son değişkeni olan içsel motivasyon ise bazı elde edilebilir sonuçlardan ziyade, içsel tatmin için bir faaliyetin gerçekleştirilmesi olarak tanımlanmaktadır. İçsel motivasyonla ilgili ilk çalışmalar 1800'lü yılların sonuna ve 1900'lü yılların başına dayanmaktadır. İçsel motivasyon ile ilgili ilk psikoloji çalışmaları 1890'lı yıllarda ampirik psikolojinin öncülerinden olan William James tarafından yapılmıştır. Daha sonrasında 1918'de içsel olarak motive olan davranışlar hakkındaki ilk teori Woodwarth tarafından öne sürülmüştür. 1950'li yıllardan sonra içsel motivasyon ile ilgili bilimsel çalışmalar çoğalmış ve içsel motivasyon olgusu psikoloji çalışmalarında yer almaya başlamıştır. Murphy ve Alexander (2000) içsel motivasyonu bir davranışın karşılığı olarak dışarıdan elde edilmeyen, fakat işin içinde mevcut olan ve kendiliğinden oluşan ödülden dolayı yaşanan duygu olarak açıklamaktadır. Brief ve Aldag (1976) içsel motivasyonu aynı zamanda bireyin kendi yeteneklerini ortaya koyma durumu olarak tanımlamıştır. Mottaz (1985)'a göre bağımsızlık, işin önemi, sorumluluk ve yaratıc1lık, kişinin yeteneklerini ve becerilerini kullanma firsatları gibi faktörler içsel motivasyon araçlarını oluşturup doğrudan işin içeriğinden kaynaklanmaktadır (Argon ve Ertürk, 2013: 161-162).

Geçiş ekonomilerinde iş dünyasındaki ahlaki bozulma firmaların etik ve sosyal davranışlara katılımını zorlaştırabilmektedir. Buna göre ahlaki bozulma sadece resmî kurumların gücünü zayıflatmakla kalmayıp, aynı zamanda tüm toplumsal yapıların anlayışını da bozmaktadır. Fulop vd. (2000)'e göre etik kodların ve sosyal sorumluluğun korunması, karmaşık ahlaki çatışmalar ve kendine özgü norm standartları nedeniyle daha zordur. Zheng, Luo ve Lu Wang (2014) Çin'de faaliyet gösteren 300 firma üzerinde yaptıkları ampirik çalışmada teorik olarak etik ve kurumsal sosyal sorumluluğun ayrı-ayrı ve birlikte, firmaları uzun vadede daha iyi performans elde etmeye nasıl yönlendirdiğinin üzerinde durmuştur. $\mathrm{Bu}$ araştırmada iş dünyasında ahlaki bozulma daha yüksek olduğunda, kurumsal sosyal sorumluluğun hem kurumsal meşruiyet hem de rekabet avantajı açısından firma performansı üzerinde daha güçlü bir olumlu etki bıraktığı bulunmuştur. Ayrıca ahlaki bozulmanın iş etiği ile kurumsal meşruiyet arasındaki pozitif bağlantıyı güçlendirdiği bulgusuna ulaşılmıştır. Sonuç olarak bir firmanın yüksek etik değerler benimsendiğinde ve kurumsal sosyal sorumluluk sergilediğinde daha iyi performans göstereceğini ve firmanın daha yüksek seviyede ahlaki bozulma içerdiği düşünülen bir ortamda faaliyet gösterdiğinde performansının daha da güçlü olacağını ileri sürmüşlerdir. Brammer ve Pavelin (2006) ve Mcwilliams ve Siegel (2001) kurumsal sosyal sorumluluk faaliyetlerini destekleyen firmaların, sosyal olarak sorumluluk sahibi olduklarını ve ekonomik olarak da sürdürülebilir olduklarını vurgulamaktadır.

Ahlaki bozulma bir toplumun sosyal normlarını ve etik kurallarını da bozmaktadır. Topluma nüfuz eden ahlaki bozulma, resmi olmayan sosyal kurumlar üzerinde çok daha kalıcı ve kapsamlı bir etki yaratabilmektedir. Durkheim (1966) modernleşmenin doğurduğu gayri resmi kurumsal değişikliklerin geleneksel normları zayıflattı̆̆ını, kültürel sapmayı ve ahlaki bozulmayı artırdığını ileri sürmektedir. Messner ve Rosenfeld (2001) meşru olsun ya da olmasın herhangi bir yolla ekonomik hedeflere ulaşma baskısının normatif kontrol mekanizmalarının 
yerini alacağını ve sonuçta resmi kurumsal gücün zayıflayacağını belirtmiştir. Apresyan (1997) ve Glinkina vd. (2001) Sovyetler Birliğinin dağılması sonrasında yaygın yolsuzluğun ve organize suçların hükümetin işlevini bozduğunu ve meşru iş faaliyetlerini engellediğini gözlemlemiştir.

Muller ve Kolk (2010)'a göre kurumsal sosyal sorumluluk faaliyetleri diş taraflarca kolayca gözlemlenebilir ve değerlendirilebilir iken etik ise örtük kurumsal inanç ve değerleri yansıtmaktadır. Basu ve Palazzo (2008) iyi tasarlanmış ve etkin bir şekilde uygulanmış kurumsal sosyal sorumluluk faaliyetlerine sahip firmaların mutlaka etik davrandığının düşünülmesinin mümkün olmadığını, çünkü bu firmaların kurumsal sosyal sorumluluk algılarının performansa ve motivasyona dayalı olacağını belirtmiştir. Jamali ve Mirshak (2007) ise kurumsal sosyal sorumluluk uygulamalarını vurgulayan etik firmaların, daha geniş sosyal kaygıları dikkate almak için dar ekonomik getirilerin ötesine bakma eğiliminde oldukları sonucuna ulaşmıştır. Buna ek olarak Fombrun ve Shanley (1990), Zhang ve Rezaa (2009) etik firmaların kurumsal sosyal sorumluluk faaliyetlerini dikkate almadıkları zaman, toplumun ihtiyaçlarını karşılamak için belirledikleri hedeflere ulaşmalarının zor olacağının altını çizmiştir. Strong vd. (2001) bir firmanın kurumsal sosyal sorumluluk ve etiğe olan bağlılığının yüksek olması halinde topluma karş1 sorumluluklarını iyi bir şekilde yerine getirebileceği sonucuna ulaşmıştır.

Valentine ve Fleischman (2008) kurumsal sosyal sorumluluğun etik kodlar ve iş tatminiyle ilişkisini incelemiştir. 313 çalışandan anket tekniği ile toplanan verilerin analizi sonucunda kurumsal sosyal sorumluluk, etik kodlar ve iş tatmini arasında pozitif yönlü ilişkiler olduğu, ayrıca kurumsal sosyal sorumluluğun etik kodlar ile iş tatmini arasındaki ilişkiye aracıllk ettiği bulunmuş̧tur. Sökmen ve Ekmekçioğlu (2013) yöneticilerin etik davranışlarının çalışanların motivasyonu ve iş tatmini üzerindeki etkisini incelemiştir. Adana'da faaliyet gösteren otellerde çalışan 836 kişiden elde edilen veriler sonucunda yöneticisinin davranışlarını etik bulan çalışanların motivasyonunun ve iş tatmininin daha yüksek olduğu sonucuna ulaşılmıştır.

Forsgren ve Haskell (2015) KSS'nin içsel ve dişsal motivasyon üzerindeki etkisini ele almıştır. Araştırmalarını Sodexo'nun İsveç şubesinde gerçekleştirmişlerdir. Sodexo, 80 ülkede 470.000'den fazla çalışanıyla, gelişmiş ve etkili KSS çalışmaları ile tanınan bir firma olup, hizmet sektöründe bir dünya lideri olarak kabul edilmektedir. Yaptıkları çalışma sonucunda, iç motivasyonun dış motivasyona göre KSS faaliyetlerinden daha fazla etkilendiğini belirtmişlerdir.

Skudeiene ve Auruskeviciene (2012)'den faydalanan Lu, Shih ve Wang (2016) kurumsal sosyal sorumluluk girişimlerinin çalışanın içsel motivasyonu ve örgütsel kimliği üzerindeki etkisini araştırmıştır. Tayvan'da restoran endüstrisinden 180 çalışan üzerinde alan araştırması yapılmıştır. Çalışma sonucunda kurumsal sosyal sorumluluk ve içsel motivasyon, kurumsal sosyal sorumluluk ve örgütsel kimlik, iç motivasyon ve örgütsel kimlik gibi değişkenler arasında anlamlı ilişkiler bulunmuştur. Ayrıca iyi bir çalışma ortamı sağlandığında, çalışanların yeteneklerini sergilemelerine olanak tanınacağ 1 ve uygun geri bildirimler sayesinde içsel motivasyonun artacağ 1 , böylece çalışanın örgütsel kimliğinin pozitif yönde gelișeceği ve organizasyonel sonuçların iyileşeceği belirtilmiştir. Kim ve Scullion (2013) kurumsal sosyal sorumluluğun çalışanların motivasyonu üzerindeki etkisini incelemiştir. Kore ve İngiltere'de gerçekleştirilen alan araştırmaları sonucunda iki değişken arasındaki ilişkinin pozitif yönlü olduğu ve bu ilişkinin ülkeler arasında farklılık gösterdiği bulunmuştur. Kurumsal sosyal sorumluluk faaliyetleri çalışanları Kore'de daha fazla aidiyet ihtiyacı yönünde motive ederken, İngiltere'de bireysel başarı yönünde motive etmektedir.

Yukarıdaki açıklamalardan hareketle aşağıdaki hipotez geliştirilmiştir:

$\mathrm{H}_{1}$ : Çalışanın kurumsal sosyal sorumluluk algısı arttıkça içsel motivasyonu artar. 
Etik iklimi bir şirketin veya bir toplumun etik davranışlarının bütünü oluşturmaktadır. Wentzel (1998) bir okuldaki sosyal ilişkiler ile motivasyon arasındaki bağlantıyı araştırmıştır. 167 öğrenciden anket tekniği aracılığıyla elde edilen veriler analiz edildiğinde okulun etik iklimi ile öğrencilerin sergilediği davranışlar, öğrenmeye yönelik motivasyonları ve okul aktivitelerine katılımları arasında pozitif yönlü ilişki olduğu belirlenmiștir. Lou vd. (2007) etik iklim algısı ile öğrencilerin okul performansı arasındaki ilișkiyi araștırmıștır. Çin'de lise öğrencisi 754 kișiden elde edilen verilerin analiziyle etik iklim ile öğrencilerin okul performansı arasında pozitif yönlü ilişki olduğu bulgusuna ulaşılmıştır. Demir ve Karakuş (2015) etik iklim ile öğretmen ve öğrencilerin motivasyon düzeyleri arasındaki ilişkiyi incelemiştir. 35 okuldan 200 öğretmen ve 621 öğrenci üzerinde gerçekleştirilen araştırmada öğretmenlerin olumlu etik davranışlar sergilemesinin öğrencilerin motivasyonunun artmasına ve kendilerini daha mutlu hissetmelerine yol açtığ 1 bulunmuştur. Ayrıca öğrencilerin de öğretmenlerine ve birbirlerine olumlu davranışlar sergilemesi sonucunda öğretmenlerin de motivasyonunun arttığı sonucuna ulaşılmıştır.

Tyagi (1982) örgütsel iklimin satış elemanlarının içsel ve dışsal motivasyonları üzerinde nasıl bir etkide bulunduğunu incelemiştir. Sigorta şirketinde çalışan 104 kişi üzerinde yürütülen araştırmayla örgüt iklimi ile ilgili olumlu algıların çalışan motivasyonunu artırdığı, ayrıca örgüt ikliminin içsel motivasyonu dışsal motivasyondan daha fazla etkilediği sonucuna ulaşılmıştır. Feng vd. (2016) etik liderlik ve çalışanların yaratıcılığı arasındaki ilişkiyi araştırmıştır. Çalışanların içsel motivasyonunu aracı değişken olarak kullanarak etik liderliğin yaratıcılık üzerindeki etkisini açıklamak için eğrisel bir modeli geliştirmişlerdir. Araştırma 258 çalışan ve liderlerinden oluşan grup üzerinde yürütülmüştür. Ulaşılan bulgulara göre etik liderlik düşük seviyeden orta seviyeye çıktıkça çalışan yaratıcılığı artmaktadır. Bununla birlikte, etik liderlik algısı orta seviyeden yüksek seviyelere çıktığında çalışanların yaratıcılıklarındaki iyileşmenin azaldığı bulunmuştur. Çalışanların içsel motivasyonunun bu eğrisel ilişkiye kısmen de olsa aracılık ettiği belirlenmiştir.

Hough, Green ve Plumlee (2016) etik çevre ve örgütsel güvenin çalışan katılımına etkisini incelemiştir. Etik bir çevre ile çalışan bağlılığ 1 arasındaki ilişkiye örgütsel güvenin aracılık ettiği bulunmuştur. Bu anlamlı pozitif ilişkiyle, çalışanların ve yöneticilerin bulundukları iş ortamındaki etik veya etik olmayan davranışlara ilişkin algılarının, kuruluşa karşı duydukları güven veya güvensizlikle doğrudan ilişkili olduğunun altını çizmişlerdir. Etik bir ortamın, çalışan katılımını arttıran örgütsel güveni doğuracağı belirtilmiştir.

Ermongkonchai (2010) çalışanların görevi kötüye kullanmasının nedenlerini incelemiştir. Büyük ölçekli sekiz işletmede görev yapan çalışanlar ve etik olmayan davranışları araştıran insan kaynakları yöneticileri ile yürütülen araştırma esnasında tüm katılımcılar, şirketlerin ciddi konularda yalan söylemesini, yetkinin kötüye kullanılmasını ve kişisel kazanç için sahtekârlı̆̆ın yapılmasını çalışan suiistimali olarak kabul ettiklerini bildirmiştir. Araştırmada elde edilen bulgular, çalışanların açgözlülük, finansal fayda veya diğer yönelimler sebebiyle etik dışı davranışlar sergilediğini ortaya koymaktadır. Ulaşılan sonuçlara dayanarak, finansal işlemleri içeren tüm suiistimallerin temel nedeninin kişisel kazanç olduğu belirtilmiştir. $\mathrm{Bu}$ kişisel kazanç ister doğrudan nakit elde etmek olsun, ister pozisyon gücünü kullanarak fayda sağlamak olsun, sonuçta çalışanların faydaları ve riskleri değerlendirdikten sonra bilinçli olarak ahlak dişı eylemleri gerçekleştirdikleri belirtilmiştir.

Wong ve Li (2015) Çin'de otel çalışanlarının etik dışı yönetimsel davranışları nasıl algıladığını araştırmıştır. Bu çalışmada aynı zamanda genel iş tatmini ile bu algı arasındaki ilişkinin keşfedilmesi de amaçlanmıştır. Araştırma sonucunda çalışanların etik olmayan yönetsel davranış algısını ortaya koyan üç temel boyut belirlenmiş ve bunlardan "çalışanlara etik dışı muamele edilmesi" boyutunun en fazla etik dışı algılanan boyut olduğu bulunmuştur. Ayrıca bu boyutun iş tatmini ile anlamlı bir şekilde ilişkili olduğu ortaya konmuştur. Ayrıca diğer iki faktör 
olan "tutulmamış sözler" ve "eşitlikten uzak ve anlayışsız muamele" de otel çalışanları tarafından etik dışı olarak algılanmıştır. Ancak bunlar genel iş tatmini ile ilişkili bulunmamıştır.

Yukarıdaki açıklamalardan hareketle aşağıdaki hipotez geliştirilmiştir:

$\mathrm{H}_{2}$ : Çalışanın ahlaki bozulma algısı arttıkça içsel motivasyonu düşer.

Çalışanların ahlaki bozulma algısı ile bulundukları örgütün kurumsal sosyal sorumluluk faaliyetlerine ilişkin algıları arasında negatif yönlü ilişki olduğunu gösteren çalışmalar bulunmaktadır. Aynı şekilde çalışanların örgütlerinin kurumsal sosyal sorumluluk faaliyetlerine ilişkin algıları ile motivasyon düzeyleri arasındaki ilişkiyi inceleyen çeşitli çalışmalar mevcuttur ve bu ilişkinin pozitif yönlü olduğu belirtilmiştir. Bu çalışmada bu ilişkilere ilave olarak çalışanın ahlaki bozulma algısının kurumsal sosyal sorumluluk algısı ile içsel motivasyon düzeyi arasındaki ilişkide düzenleyici / biçimlendirici bir etkiye sahip olduğu öngörülmektedir. Buna göre çalışanın ahlaki bozulma algısı arttıkça kurumsal sosyal sorumluluk algısının içsel motivasyona etkisinin artması beklenir; zira iş hayatında etik normların etkisiz kaldığını ve etik dış1 davranışların yaygınlaştığını düşünen kişi çalıştı̆̆ örgütün bu olumsuz çevreye rağmen kurumsal sosyal sorumluluk faaliyetleri yürüttüğünü düşündüğünde bu faaliyetlerin içsel motivasyonu üzerindeki olumlu etkisi güçlenebilir.

Yukarıdaki açıklamalardan hareketle aşağıdaki hipotez geliştirilmiştir:

$\mathrm{H}_{3}$ : Çalışanın ahlaki bozulma algısı arttıkça kurumsal sosyal sorumluluk algısının içsel motivasyon üzerindeki etkisi artar.

\section{YÖNTEM}

Yukarıda kuramsal çerçevede açıklanan hipotezlerden hareketle araştırma modeli aşağıdaki gibi oluşturulmuştur:

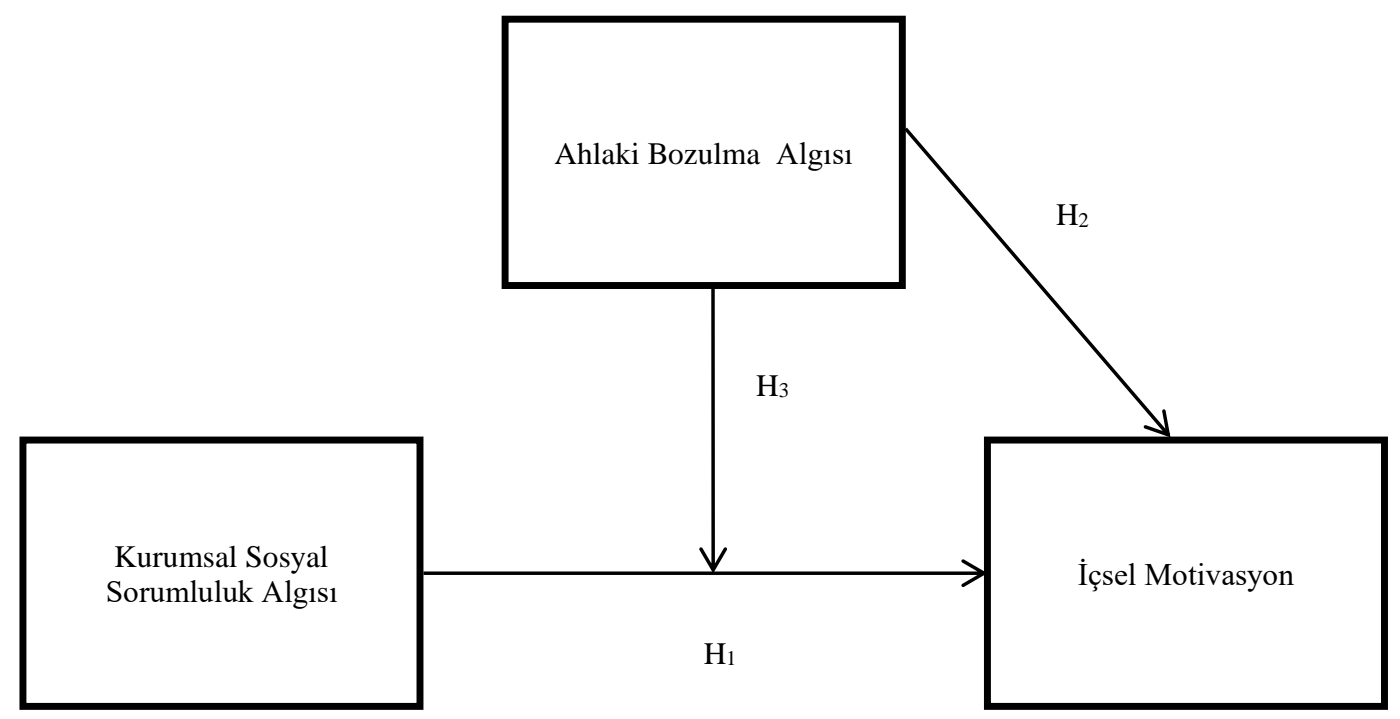

Şekil 1: Araştırma Modeli

\subsection{Araştırma Evreni ve Örneklem}

Bu araştırma Türkmenistan'ın Türkmenabat şehrindeki bir sağlık kuruluşunun çalışanları üzerinde gerçekleştirilmiştir. Türkmenistan eskiden Sovyetler Birliğinin bir parçası iken bugün geçiş ekonomisi özelliği gösteren bir ülkedir. Coğrafi konumu sayesinde önemli bir stratejik 
güce ve başta doğal gaz olmak üzere pek çok kaynağa sahip olan Türkmenistan'da işgücü piyasasına ve ekonomiye kamu sektörü ve kamu iktisadi kuruluşları egemen durumdadır. Hükumetin sanayi politikası ithalatı azaltmak, tek bir müşteriye bağlı kalmanın doğurduğu zayıflığın üstesinden gelmek için gaz ihracat rotalarını mevcut boru hatlarının ötesine taşıyarak çeşitlendirmek ve hidrokarbon dışı faaliyetleri teşvik etmektir. Ancak katı yönetsel kontroller, döviz eksikliğinin yol açtığı sıkıntılar, kamu sektörünün ekonomik faaliyetlerdeki katı ve hantal tutumu özel sektörün gelişmesinin ve ekonomik çeşitlendirmenin önündeki en büyük engeller olmaya devam etmektedir (https://www.worldbank.org/en/country/turkmenistan). Araştırmanın ana kütlesini Türkmenistan'ın Türkmenabat şehrinde bulunan bir devlet hastanesinde faaliyet gösteren 193 çalışan oluşturmaktadır. Belirlenen ana kütleden \%95 güven düzeyinde $\% 5$ hata payı ile seçilen 129 çalışan araştırmanın örneklemini oluşturmaktadır (https://www.surveysystem.com/sscalc.htm). Yeterli örneklem büyüklüğüne ulaşmak amaciyla basit tesadüfi örnekleme yöntemiyle belirlenen toplam 140 kişiye bir uzman doktor aracıllğıyla ulaşılmış, yüz yüze anket uygulanmış ve veriler toplanmıştır. Alan araştırması için etik kurul onayı alınmıştır.

\subsection{Veri Toplama Araçları}

Araştırmada verileri toplamak için anket tekniği kullanılmıştır. Soru formunu oluşturabilmek için gerekli literatür taraması yapılmış olup daha önceki yapılan çalışmalarda güvenirliliği ve geçerliliği ispatlanmış ölçeklerle soru formu oluşturulmuştur. Seçilen ölçeklerin orijinal dilinin İngilizce olması nedeniyle ölçekler İngilizceye hâkim olan bir alan uzmanı tarafından önce İngilizceden Türkçeye, sonrasında ise Türkçeden İngilizceye tercüme edilmiş ve değerlendirmeler sonucunda anlam kayması olmadığı gözlenmiştir. Ayrıca örneklemin yer aldığı ülkede Rusçanın yaygın kullanıma sahip olması sebebiyle ölçekler Rus dili ve Edebiyatı bölümünden bir uzman yardımı ile önce Türkçeden Rusçaya ve sonrasında da Rusçadan Türkçeye tercüme edilmiş ve değerlendirmeler sonucunda anlam kayması olmadığı gözlenmiştir.

Kullanılan soru formu iki bölümden ve 31 maddeden oluşmaktadır. İlk bölüm 7 sorudan oluşmakta olup demografik özellikleri (cinsiyet, yaş, eğitim durumu, statü, idari görev, gelir durumu ve deneyim süresi) ölçmeye yöneliktir. İkinci bölümde içsel motivasyon, ahlaki bozulma ve kurumsal sosyal sorumlulukla ilgili ölçekler yer almaktadır. İçsel motivasyon Kuvaas (2006) tarafindan oluşturulan ve daha sonra Kuvaas ve Dysvik (2009) tarafindan geliştirilen altı maddelik ölçekle ölçülmüştür. Çalışanların iş hayatında ahlaki bozulma algısını ölçmek için Zheng vd. (2014) tarafindan geliştirilen 4 maddelik ölçek kullanılmıştır. Cevaplayıcılardan söz konusu 4 soruyu hem günümüzün iş çevresi için hem de 10 y1l önceki iş çevresi için cevaplamaları istenmiş, bu cevaplar arasındaki farkın derecesine göre ahlaki bozulma algısı ölçülmüştür. Çalışanların içsel kurumsal sosyal sorumluluk algısı Lindgreen vd. (2009) tarafından geliştirilen 6 maddelik ölçekle, dişsal kurumsal sosyal sorumluluk algısı ise Menon ve Kahn (2003) tarafından oluşturulan 4 maddeyle ölçülmüştür. İkinci bölümdeki tüm ölçekler 5'li Likert ölçeği tipindedir (1-Kesinlikle Katılmıyorum .... 5-Kesinlikle Katılıyorum).

\subsection{Verilerin Analizi}

Kullanılan ölçeklerin güvenilirliğini test etmek amacıyla örneklemden 50 kişi üzerinde ön test çalışması yapılmış olup ulaşılan bulgular soruların cevaplayıcılar tarafından anlaşıldığını ve ölçeklerin beklenen yapı ve özellikleri sergilediğini ortaya koymuştur. Soru formları aracılığıyla elde edilen verilerin analizi yapılmadan önce tüm soru forumları gözden geçirilmiş, eksik ve hatalı işaretlenen ve geçersiz olanlar elenmiş̧ir. Geriye kalan soru forumlarından toplanan veriler IBM SPSS 25 programı ile analiz edilmiştir. Öncelikle örneklemin demografik değişkenler yönünden dağılımı ortaya konulmuştur. Daha sonra kullanılan ölçeklere açıklayıcı faktör analizi ve güvenilirlik analizi uygulanarak değişkenlerin faktör yapısı belirlenmiştir. 
Bunun ardından değişkenler arasındaki ilişkiler korelasyon analiziyle incelenmiş ve regresyon analizleri yapılarak araştırma hipotezleri test edilmiştir.

\section{BULGULAR}

Araştırmaya katılanların demografik özellikler yönünden dağılımı Tablo 1'de gösterilmiştir:

Tablo 1: Örneklemin Demografik Özellikler Yönünden Dağılımı

\begin{tabular}{|c|c|c|c|}
\hline \multirow[t]{2}{*}{ Cinsiyet } & Kadın & 89 & 69,0 \\
\hline & Erkek & 40 & 31,0 \\
\hline \multirow[t]{6}{*}{ Yaş } & 25 yaş ve altı & 3 & 2,3 \\
\hline & $26-30$ yaş & 33 & 25,6 \\
\hline & $31-35$ yaş & 38 & 29,5 \\
\hline & $36-40$ yaş & 28 & 21,7 \\
\hline & $41-45$ yaş & 19 & 14,7 \\
\hline & 45 yaş ve üzeri & 8 & 6,2 \\
\hline \multirow[t]{5}{*}{ Eğitim } & İlköğretim & 0 & 0 \\
\hline & Lise & 36 & 27,9 \\
\hline & Yüksekokul & 33 & 25,6 \\
\hline & Lisans & 56 & 43,4 \\
\hline & Lisansüstü & 4 & 3,1 \\
\hline \multirow[t]{2}{*}{ İdari görev } & Evet & 13 & 10,1 \\
\hline & Hayır & 116 & 89,9 \\
\hline \multirow[t]{4}{*}{ Gelir Düzeyi* } & $2500 \mathrm{TL}$ ve altı & 4 & 3,1 \\
\hline & $2501-4000 \mathrm{TL}$ & 54 & 41,9 \\
\hline & $4001-5500 \mathrm{TL}$ & 51 & 39,5 \\
\hline & 5501 TL ve üzeri & 20 & 15,5 \\
\hline \multirow[t]{5}{*}{ Çalışma Süresi } & $1-5$ y1l & 39 & 30,2 \\
\hline & $6-10$ y1l & 38 & 29,5 \\
\hline & $11-15$ y1l & 28 & 21,7 \\
\hline & $16-20$ y1l & 15 & 11,6 \\
\hline & 21 yıl ve üzeri & 9 & 7,0 \\
\hline
\end{tabular}

*Gelir düzeyi Türk Lirasına çevrilerek gösterilmiştir. 
Tablo 1'de görüldüğü gibi katılımcıların \%69'u kadın, \%31'i erkektir. Katılımcıların çoğunun 31-35 yaş arasında olduğu $(\% 29,5)$ ve \%43,4'ünün lisans mezunu oldukları görülmektedir. İdari görevi olanlar örneklemin \%10,1'ini oluştururken, 2501-4001 TL arasında gelir elde edenler \%41,9'unu oluşturmaktadır. Ayrıca 1-5 yıldır çalışanlar örneklemin $\% 30,2$ 'sini oluşturmaktadır.

Öncelikle verilerin açıklayıcı faktör analizine uygun olup olmadığı incelenmiştir. Ölçeklerin faktör analizine uygunluğu örneklem yeterliliği (Kaiser-Meyer-Olkin-KMO) ve Bartlett küresellik testi ile test edilmektedir. Analizlerde kullanılan ölçeklere Bartlett küresellik testi ve KMO testi uygulanmıştır. Testler sonucunda Kaiser-Meyer-Olkin (KMO) değeri 0,904 olarak bulunmuştur. Bu değerin 0,70’ten yüksek olması ölçeklerin faktör analizine uygunluğunu belirtmektedir. Küresellik testi oranlarına (Bartlett test of sphericity) ilişkin değerin 0,000 olması verilerden anlamlı faktörler çıkacağını ortaya koymaktadır. Soru formunda kullanılan ölçeklere uygulanan açıklayıcı faktör analizinin sonuçları Tablo 2'de özetlenmiştir:

Tablo 2: Açıklayıcı Faktör Analizi Sonuçları

\begin{tabular}{|c|c|c|c|c|c|}
\hline & $\begin{array}{c}\text { Faktör } \\
\text { Yükü }\end{array}$ & $\begin{array}{c}\text { Öz } \\
\text { Değer }\end{array}$ & $\begin{array}{c}\text { Açılkanan } \\
\text { Varyans }\end{array}$ & $\begin{array}{c}\text { Toplam } \\
\text { Açılanan } \\
\text { Varyans }\end{array}$ & $\begin{array}{c}\text { Cronbach } \\
\text { Alfa }\end{array}$ \\
\hline 1. Faktör: İçsel Motivasyon & & 9,923 & 25,353 & 25,353 & 0,965 \\
\hline İçsel motivasyon- 2 & 0,873 & & & & \\
\hline İçsel motivasyon- 3 & 0,870 & & & & \\
\hline İçsel motivasyon- 5 & 0,838 & & & & \\
\hline İçsel motivasyon- 4 & 0,834 & & & & \\
\hline İçsel motivasyon- 1 & 0,825 & & & & \\
\hline İçsel motivasyon- 6 & 0,789 & & & & \\
\hline 2. Faktör: Kurumsal Sosyal Sorumluluk & & 3,692 & 22,617 & 47,670 & 0,934 \\
\hline Dişsal kurumsal sosyal sorumluluk-1 & 0,856 & & & & \\
\hline İçsel kurumsal sosyal sorumluluk- 4 & 0,830 & & & & \\
\hline İçsel kurumsal sosyal sorumluluk- 5 & 0,822 & & & & \\
\hline İçsel kurumsal sosyal sorumluluk- 6 & 0,811 & & & & \\
\hline Dişsal kurumsal sosyal sorumluluk- 4 & 0,736 & & & & \\
\hline Dişsal kurumsal sosyal sorumluluk- 2 & 0,657 & & & & \\
\hline $\begin{array}{l}\text { 3. Faktör: Günümüze İliş̧kin Ahlaki Durum } \\
\text { Algısı }\end{array}$ & & 2,125 & 19,463 & 67,433 & 0,979 \\
\hline Ahlaki durum -2 & 0,929 & & & & \\
\hline
\end{tabular}




\begin{tabular}{|c|c|c|c|c|c|}
\hline Ahlaki durum- 3 & 0,927 & & & & \\
\hline Ahlaki durum- 1 & 0,895 & & & & \\
\hline Ahlaki durum- 4 & 0,885 & & & & \\
\hline $\begin{array}{l}\text { 4. Faktör: } 10 \text { Yıl Önceye İlişsin Ahlaki Durum } \\
\text { Algısı }\end{array}$ & & 1,559 & 19,063 & 86,496 & 0,981 \\
\hline On y1l önceki ahlaki durum- 3 & 0,978 & & & & \\
\hline On y1l önceki ahlaki durum -2 & 0,975 & & & & \\
\hline On y1l önceki ahlaki durum- 1 & 0,973 & & & & \\
\hline On y1l önceki ahlaki durum- 4 & 0,949 & & & & \\
\hline
\end{tabular}

Tablo 2'de görüldüğü gibi soru formundaki değişkenler 4 faktörlü bir yapıda toplanmıştır. Yapılan faktör analizinde bazı maddeler (İçsel kurumsal sosyal sorumluluk-1, İçsel kurumsal sosyal sorumluluk-2, İçsel kurumsal sosyal sorumluluk-3 ve Dişsal kurumsal sosyal sorumluluk- 3) birden fazla faktöre yüklendiği için analizden çıkarılmıştır. Elde edilen dört alt faktörün öz değerleri 1,559 ile 9,923 arasında değişmekte olup bunlar toplam varyansın yaklaşık \%87'sini açıklamaktadır. Elde edilen faktörlere ilişkin Cronbach Alfa değerleri 0,981 ile 0,934 arasında değişmekte olup tüm faktörlerin güvenilir olduğu anlaşılmıştır.

İçsel motivasyon, kurumsal sosyal sorumluluk algisı ve ahlaki bozulma algis1 değişkenlerinin ortalaması, standart sapması ve bunlar arasındaki ilişkileri gösteren Pearson korelasyon katsayıları Tablo 3'te gösterilmiştir:

Tablo 3: İçsel Motivasyon, Kurumsal Sosyal Sorumluluk Algısı ve Ahlaki Bozulma Algısı Arasındaki İlișkiler

\begin{tabular}{lccccc}
\hline Değişkenler & Ortalama & $\begin{array}{c}\text { Standart } \\
\text { Sapma }\end{array}$ & $\begin{array}{c}\text { Iccsel } \\
\text { Motivasyon }\end{array}$ & $\begin{array}{c}\text { Kurumsal } \\
\text { Sosyal } \\
\text { Sorumluluk } \\
\text { Algısı }\end{array}$ & $\begin{array}{c}\text { Ahlaki Bozulma } \\
\text { Algısı }\end{array}$ \\
\hline İçsel Motivasyon & 4,11 & 0,94 & 1 & \\
\hline Kurumsal Sosyal & Sorumluluk & 4,09 & 0,85 &, $679 * *$ & 1 \\
\hline Ahlaki Bozulma Algısı & 0,41 & 1,48 &,$- 378^{* *}$ &,$- 297 * *$ & 1 \\
\hline
\end{tabular}

$* * p<0,01$

Tablo 3’te görüldüğü gibi bütün ilişkiler 0,01 önem düzeyinde anlamlıdır. Ayrıca içsel motivasyon ile kurumsal sosyal sorumluluk algısı arasında güçlü ve pozitif yönlü bir ilişki vardır $(\mathrm{r}=0,679)$, yani kurumsal sosyal sorumluluk algısı arttıkça içsel motivasyon düzeyi de artmaktadır. İçsel motivasyon ile ahlaki bozulma arasında orta düzeyde ve negatif yönlü ilişki vardır $(\mathrm{r}=-0,378)$, bu da ahlaki bozulma algısının artması halinde içsel motivasyon düzeyinin 
azalacağını göstermektedir. Ahlaki bozulma algısı ile kurumsal sosyal sorumluluk algısı arasında ise zayıf ve negatif yönlü ilişki bulunmaktadır $(\mathrm{r}=-0,297)$, yani ahlaki bozulma algısı arttıkça kurumsal sosyal sorumluluk algısı zayıflamaktadır.

Korelasyon analizi ile değişkenler arasında anlamlı bir ilişki olduğu sonucuna ulaşıldıktan sonra, araştırmanın hipotezlerini test etmek için dört aşamalı hiyerarşik regresyon analizi yapılmıştır. Araştırmanın hipotezlerinin anlamlı sonuca ulaşıp ulaşmayacağına karar verilirken, mevcut regresyon denklemlerindeki $\beta$ katsayıları ve onlara yeni ilave edilen değiş̧kenler sonucunda R2 değerindeki değişim dikkate alınmıştır. Ayrıca R2'deki değişimin istatistiksel yönden ne kadar anlamlı olduğunu gösteren $F$ değerleri de dikkate alınmıştır. Biçimlendirici (düzenleyici) değişkenlerin yer aldığg regresyon denklemlerinde çoklu doğrusallık sorununun doğmasını engellemek için bağımsız değişkenler olan kurumsal sosyal sorumluluk algısı ve ahlaki bozulma algısının standardize değerleri ( $Z$ değerleri) hesaplanmış ve bu değerler denkleme katılmıştır. Ayrıca düzenleyici/biçimlendirici değişkeni oluşturmak için de söz konusu iki değişkenin standardize değerlerinin çarpımı yapılmıştır.

Çoklu doğrusallık probleminin olmadığ 1 belirlendikten sonra, kurumsal sosyal sorumluluk ve ahlaki bozulma boyutları bağımsız değișken, içsel motivasyon boyutu ise bağımlı değişken olarak alınmıştır ve dört aşamalı hiyerarşik regresyon analizi yapılmıştır. Analiz sonuçları Tablo 4'te özetlenmiştir:

Tablo 4: Hiyerarşik Regresyon Analizi Sonuçları

\begin{tabular}{|c|c|c|c|c|c|c|}
\hline & Değişkenler & $\boldsymbol{\beta}$ & $\mathbf{t}$ & $\mathbf{p}$ & VIF & Tolerans \\
\hline \multirow[t]{2}{*}{ 1.Adim } & Cinsiyet &,- 044 &,- 503 & ,616 & 1,000 & 1,000 \\
\hline & İdari Görev &, $201 *$ & 2,303 &, 023 & 1,000 & 1,000 \\
\hline \multirow[t]{3}{*}{ 2.Adım } & Cinsiyet & 019 &, 303 & ,762 & ,991 & 1,009 \\
\hline & İdari Görev &, $178 * *$ & 2,789 & ,006 & ,999 & 1,001 \\
\hline & KSS Algis1 &, $674 * * *$ & 10,530 &, 000 & ,990 & 1,010 \\
\hline \multirow[t]{4}{*}{ 3. Adım } & Cinsiyet &, 045 & ,713 & ,477 &, 970 & 1,031 \\
\hline & İdari Görev &, $161 * *$ & 2,576 &, 011 & ,989 & 1,011 \\
\hline & KSS Alg1s1 &, $623 * * *$ & 9,571 &, 000 &, 910 & 1,099 \\
\hline & Ahlaki Bozulma Algisı &,$- 184 * *$ & $-2,792$ &, 006 &, 884 & 1,131 \\
\hline \multirow[t]{5}{*}{ 4.Adım } & Cinsiyet & ,046 & ,760 & ,448 & ,970 & 1,031 \\
\hline & İdari Görev &, $145^{*}$ & 2,417 &, 017 & ,984 & 1,017 \\
\hline & KSS Algis1 &, $548 * * *$ & 8,340 &, 000 &, 816 & 1,225 \\
\hline & Ahlaki Bozulma Algisi &,$- 153 * *$ & $-2,400$ &, 018 &, 867 & 1,153 \\
\hline & $\begin{array}{l}\text { KSS Algisı x Ahlaki } \\
\text { Bozulma Algis1 }\end{array}$ &, $229 * *$ & 3,539 &, 001 &, 840 & 1,190 \\
\hline
\end{tabular}




\begin{tabular}{ccccc}
\hline $\mathrm{R}^{2}$ &, 042 &, 492 &, 522 &, 567 \\
\hline Düzeltilmiş $\mathrm{R}^{2}$ &, 027 &, 480 &, 507 &, 549 \\
\hline $\mathrm{F}$ & 2,781 & $40,432 * * *$ & $33,921^{* * * *}$ & $32,163 * * *$ \\
\hline$\Delta \mathrm{R}^{2}$ &, 042 &, $450 * * *$ &, $030^{* *}$ &, $044 *$ \\
\hline Durbin-Watson: $1,634^{*}$ & ${ }^{*} p<0,05$ & ${ }^{* * p<0,01}$ & ${ }^{* * *} p<0,001$ &
\end{tabular}

Tablo 4'te regresyon analizinin her aşamasında yer alan değişkenlere ait $\beta$ değerleri, $\mathrm{R}^{2}$, düzeltilmiş $\mathrm{R}^{2}$, $\mathrm{F}$ değeri ve $\Delta \mathrm{R}^{2}$ değerleri gösterilmiştir. Tablodan da görüldüğü gibi, "cinsiyet" ve "idari görev" kontrol değişkenleri olarak belirlenmiştir. Regresyon analizi yapıldığı zaman bazı varsayımların sağlanıp sağlanmadığı önemlidir, bu varsayımların en önemlilerinden biri de hataların bağımsızlığı varsayımıdır. Bu varsayımın sağlanıp sağlanmadığını ölçmek için DurbinWatson testi uygulanır. Test sonucunda elde edilen Durbin-Watson değerinin 2'ye yakın olmas1 varsayımın doğrulandığını ifade ederken, 1'den küçük ya da 3'ten büyük olması sorunun varlığını belirtmektedir (Field, 2009:220-221). İçsel motivasyona ilişkin hiyerarşik regresyon analizi sonuçlarına göre Durbin-Watson katsayısı 1,634'tür. Regresyon analizinin ilk aşamasında kontrol değişkenleri bağımsız değişkenler, içsel motivasyon ise bağımlı değişken olarak regresyona katılmıştır (Model 1). Sadece kontrol değişkenlerinden oluşan bu denklem istatistiksel olarak anlamlı değildir $(\mathrm{F}=2,781, \mathrm{p}>0,05)$.

İkinci aşamada hiyerarşik regresyon analizine "kurumsal sosyal sorumluluk algısı" değişkeni eklenmiştir (Model 2). Yeni oluşan regresyon denklemi içsel motivasyon değişkenindeki varyansın \%48'ini açıklamaktadır ve 0,001 güven düzeyinde anlamlıdır (Düzeltilmiş $\mathrm{R}^{2}=0,48$ ve $\mathrm{F}=40,432$ ). Bu denklemin açıklama gücü birinci aşamadaki sadece kontrol değişkenlerinden oluşan denklemin açıklama gücünden yüksektir $\left(\Delta R^{2}=0,450\right)$ ve aradaki fark istatistiksel açıdan anlamlıdır $(\mathrm{p}<0,001)$. Bu farktan hareketle, ikinci aşamadaki modelin içsel motivasyon değişkenini birinci aşamadaki modele göre daha iyi açıkladığı söylenebilir. İkinci modelde idari görev değişkeninin katsayısı istatistiksel açıdan anlamlıdır $(\beta=0,178$ ve $\mathrm{p}<0,01)$. Dolayısıyla bu modele göre idari görevin içsel motivasyonu artırdığı söylenebilir. Çalışanın kurumsal sosyal sorumluluk algısının da içsel motivasyon düzeyini istatistiksel açıdan anlamlı derecede artırdığı bulunmuştur $(\beta=0,674$ ve $p<0,01)$. Bu sonuca göre $\mathrm{H}_{1}$ hipotezi kabul edilmiştir.

Üçüncü aşamada hiyerarşik regresyon analizine "ahlaki bozulma" değişkeni dâhil edilmiştir (Model 3). Bu değişkenin eklenmesi sonucu oluşan regresyon denklemi içsel motivasyon değişkenindeki varyansın yaklaşık \%51'ini açılamaktadır ve denklem 0,001 güven düzeyinde anlamlıdır (Düzeltilmiş $\mathrm{R}^{2}=0,507$ ve $\mathrm{F}=33,921$ ). Üçüncü aşamadaki açıklama gücü ikinci aşamadaki denklemin açıklama gücünden $\% 3$ daha fazladır $\left(\Delta \mathrm{R}^{2}=0,030\right.$ ve $\left.\mathrm{p}<0,05\right)$. Ayrıca ahlaki bozulma değişkenine ait beta katsayısı negatiftir $(\beta=-, 184)$ ve istatistiksel açıdan anlamlıdır. Elde edilen bulgular sonucunda çalışanın ahlaki bozulma algısı arttıkça içsel motivasyonunun düşeceğini öne süren $\mathrm{H}_{2}$ hipotezi kabul edilmiştir.

Son olarak dördüncü aşamada hiyerarşik regresyon analizine bir önceki adımdakilere ek olarak kurumsal sosyal sorumluluk ve ahlaki bozulma değişkenlerinin etkileşimi dahil edilmiştir. Bu denklem (Model 4) bütün olarak anlamlı bulunmuştur $(\mathrm{F}=32,163$ ve $\mathrm{p}<0,001)$ ve bu denklem içsel motivasyondaki değişimin yaklaşık \%55'ini açıklamaktadır (Düzeltilmiş $\mathrm{R}^{2}=0,549$ ). Bir önceki denkleme göre açıklama gücü $\% 4$ daha fazladır $\left(\Delta \mathrm{R}^{2}=0,044\right.$ ve $\left.\mathrm{p}<0,05\right)$. Etkileşim değişkeni incelendiğinde istatistiksel açıdan anlamlı, ancak pozitif bir katsayıya sahip olduğu görülmektedir. Tablo 8'de özetlendiği gibi, çalışanların ahlaki bozulma algısının artması 
durumunda, kurumsal sosyal sorumluluğun içsel motivasyona etkisi artmaktadır (KSS x Ahlaki Bozulma değişkeni için $\beta=0,229$ ve $\mathrm{p}<0,05)$. Elde edilen sonuçlara göre, çalışanın ahlaki bozulma algisı arttıkça kurumsal sosyal sorumluluğun içsel motivasyon üzerindeki etkisinin artacağını belirten $\mathrm{H}_{3}$ hipotezi kabul edilmiştir.

Araştırma bulgularını genel olarak değerlendirmek gerekirse, çalışmanın literatür taramas1 kısmında gözlendiği gibi kurumsal sosyal sorumluluk faaliyetlerinin tüm dünyada giderek daha fazla önemsenen bir konu olması sebebiyle bu faaliyetleri gerçekleştiren işletmelerin çalışanlarının içsel motivasyonlarının güçlenmesi beklenir. Öte yandan bu çalışanların bulunulan ülkedeki ekonomik işleyişe ilişkin ahlaki bozulma algısının içsel motivasyonlarını zayıflatması beklenir. Ancak ahlaki bozulma algısının etkisi bununla sınırlı kalmayabilir; çünkü bir ülkede etik dışı uygulamaların çoğaldığının düşünülmesi gönüllülük esasıyla yürütülen ve gerek çalışanlar gerekse tüm toplum tarafından değerli algılanan sosyal sorumluluk faaliyetlerinin çalışanların içsel motivasyonuna yapacağı olumlu etkiyi güçlendirici rol oynayabilir. $\mathrm{Bu}$ ortamda çalışanların işletmelerinin sosyal sorumluluk faaliyetlerine atfettikleri anlam güçlenebilir ve işletmelerine duydukları güven artabilir. Bu durum onların içsel motivasyonlarına da etki edecektir.

\section{SONUC}

Bu çalışmada kurumsal sosyal sorumluluk, toplumdaki ahlaki bozulma ve çalışanların içsel motivasyon düzeyi arasındaki ilişkileri açıklamak amaçlanmıştır. Yapılan bazı araştırmalarda Sovyetler Birliğinin son dönemlerinde yaygın yolsuzluğun ve organize suçun hükümetin işlevini bozduğu ve meşru iş faaliyetlerini engellediği belirtilmiştir. Sovyetler Birliğinin dağılması sonucunda bu durumun bağımsızlığını kazanan diğer ülkeler üzerinde ne kadar etki yarattığı merak uyandıran konulardan biri haline gelmiştir. Bu sebeple bu araştırma eski Sovyetler Birliğinin ve günümüzde de Orta Asya'nın en gelişmiş ülkelerinden biri olan Türkmenistan'da yapılımışır. Araştırmanın ana kütlesini Türkmenistan'ın Türkmenabat şehrinde bulunan bir devlet hastanesinde faaliyet gösteren 193 çalışan oluşturmaktadır. Bu ana kütleden $\% 95$ güven düzeyinde $\% 5$ hata pay1 ile seçilecek örneklemin büyüklüğü 129 'dur. Belirtilen örneklemden elde edilen veriler IBM SPSS 25.0 programı ile analize tabi tutulmuştur. Öncelikle örneklemin demografik değişkenler yönünden dağılımı ortaya konmuştur. Daha sonra açıklayıcı faktör analizi ve güvenilirlik analizleri yapılmış, ardından korelasyon ve regresyon analizi yapılmıştır. Ulaşılan tüm bulgular bu örneklemle sınırlı olup geçiş ekonomisi özelliği gösteren ülkelerdeki bütün işletmeler için istatistiksel açıdan anlamlı genellemeler yapmaya imkân tanımamaktadır. Analizler sonucunda ulaşılan bulgular aşağıdaki gibi özetlenebilir:

Araştırmaya katılanların ahlaki bozulma algısını ölçmek için bugünkü ahlaki yozlaşmışlık düzeyine ilişkin değerler ile on yıl önceki ahlaki yozlaşmışlık düzeyine ilişkin değerler arasındaki fark hesaplanmış olup ahlaki bozulma değişkeni oluşturulmuştur. Bu değişkenin ortalaması 0,41 iken standart sapmas1 1,48 bulunmuştur. Bu değişkenin aldığ en düşük değer -3, 00 iken aldığı en yüksek değer 4,00'dır.

$\mathrm{Bu}$ çalışmada çalışanların kurumsal sosyal sorumluluk algısı, ahlaki bozulma algısı ve içsel motivasyon düzeyleri arasındaki ilişkileri ölçmek için öncelikle korelasyon analizi uygulanmıştır. Elde edilen sonuçlara göre bütün korelasyonlar 0,01 önem düzeyinde anlamlıdır. Ayrıca içsel motivasyon ile kurumsal sosyal sorumluluk arasında $(r=0,679)$ güçlü ve pozitif yönlü ilişki bir vardır; yani çalışanın kurumsal sosyal sorumluluk algısı arttıkça içsel motivasyon düzeyi de artmaktadır. İçsel motivasyon ile ahlaki bozulma algısı arasında $(\mathrm{r}=-0,378)$ orta düzeyde ve negatif yönlü ilişki vardır. Bu da çalışanın ahlaki bozulma algısının artması halinde içsel motivasyon düzeyinin azaldığını göstermektedir. Ahlaki bozulma algısı ile kurumsal sosyal sorumluluk algısı arasında da $(\mathrm{r}=-0,297)$ zayıf ve negatif yönlü bir ilişki bulunmaktadır. $\mathrm{Bu}$ 
katsayıya göre çalışanın ahlaki bozulma algısı arttıkça kurumsal sosyal sorumluluk algısı azalmaktadır.

Korelasyon analizi yapıldıktan sonra araştırmanın hipotezlerini test etmek için dört aşamalı hiyerarşik regresyon analizi yapılmıştır. Biçimlendirici (düzenleyici) değişkenlerin yer aldığı regresyon denklemlerinde çoklu doğrusallık sorununun doğmasını engellemek için bağımsız değişkenler olan kurumsal sosyal sorumluluk algısı ve ahlaki bozulma algısının standardize değerleri ( $\mathrm{Z}$ değerleri) hesaplanmış ve bu değerler denkleme katılmıştır. Ayrıca düzenleyici/biçimlendirici değişkeni oluşturmak için de söz konusu iki değişkenin standardize değerlerinin çarpımı yapılmıştır. Hiyerarşik regresyon analizinden elde edilen sonuçlar şu şekilde özetlenebilir:

İlk regresyon modelinde içsel motivasyon bağımlı değişken olarak alınırken yalnızca kontrol değişkenlerine denklemde yer verilmiştir. Ulaşılan bulgulara göre bu denklem istatistiksel açıdan anlamlı değildir.

İkinci regresyon modelinde kontrol değişkenlerine ilaveten kurumsal sosyal sorumluluk algısı bağımsız değişken olarak modele katılmıştır. Analiz sonuçlarına göre oluşturulan denklem istatistiksel olarak anlamlıdır ve cinsiyet, idari görev ve kurumsal sosyal sorumluluk algıs1 değişkenleri birlikte içsel motivasyondaki değişimin \%48'ini açıklamaktadır. Cinsiyet değişkeninin beta katsayısı istatistiksel açıdan anlamlı değilken idari görev ve kurumsal sosyal sorumluluk algısı değişkenlerinin katsayısı anlamlı (sırasıyla $p<0,05$ ve $p<0,01$ ) ve pozitiftir. $\mathrm{Bu}$ bulgulara göre idari görev sahibi olmanın içsel motivasyonu artırdığı görülmektedir. Aynı şekilde çalışanın kurumsal sosyal sorumluluk algısının artması durumunda içsel motivasyonunun da arttığ 1 gözlenmiştir. Diğer bir deyişle çalışanın bulunduğu işletmenin sosyal sorumluluk faaliyetlerini yerine getirdiğini düşünmesi onu içsel olarak motive etmektedir. Buna göre, çalışanın kurumsal sosyal sorumluluk algısı arttıkça içsel motivasyon düzeyinin de artacağını öne süren $\mathrm{H}_{1}$ hipotezi kabul edilmiştir. Elde edilen sonuçlar daha önce yapılan çalışmaların bulgularıyla örtüşmektedir. Örneğin Forsgren ve Haskel (2015) ve Lu, Shih ve Wang (2016) kurumsal sosyal sorumluluk ile içsel motivasyon arasında pozitif yönlü ilişki olduğunu belirtmiştir. Kurumsal sosyal sorumluluk ile çalışan motivasyonu arasındaki ilişkiyi inceleyen Kim ve Scullion (2013) da bu iki değişken arasında pozitif yönlü ilişki olduğu sonucuna ulaşmıştır.

Üçüncü aşamada regresyon analizine ahlaki bozulma algısı değişkeni eklenmiştir. Cinsiyet, idari görev, kurumsal sosyal sorumluluk algısı ve ahlaki bozulma algısı değişkenlerini içeren denklem istatistiksel açıdan anlamlıdır ve içsel motivasyondaki değişimin yaklaşık $\% 51$ 'ini açıklamaktadır. Bu denklemin açıklama gücü bir önceki denklemden istatistiksel açıdan anlamlı düzeyde yüksektir $\left(\Delta \mathrm{R}^{2}=0,030\right.$ ve $\left.\mathrm{p}<0,05\right)$. Ayrıca ahlaki bozulma değişkenine ait beta katsayısı negatiftir $(\beta=-, 184)$ ve istatistiksel açıdan anlamlıdır $(\mathrm{p}<0,05)$. Elde edilen bulgular sonucunda çalışanın ahlaki bozulma algısı arttıkça içsel motivasyonunun düşeceğini öne süren $\mathrm{H}_{2}$ hipotezi kabul edilmiştir. Yani ahlaki bozulma algısı arttıkça çalışanın içsel motivasyonunda azalma olmaktadır. Diğer bir deyişle iş hayatında geçmişle karşılaştırıldığında ahlaki değerlerin yitirildiğini ve etik dışı tutum ve davranışların yaygınlaştığını düşünen çalışanların içsel motivasyonu zayıflamaktadır. Ulaşılan sonuca benzer sonuç elde eden Ermongkonchai (2010) ahlak dışı davranışların çalışanın motivasyonunu azalttığını vurgulamıştır. Ayrıca Wong ve Li (2015) etik dışı yönetsel davranışların çalışanın motivasyonu üzerindeki etkisini inceledikleri çalışmada bu çalışmada ulaş1lan bulgularla örtüşen bulgulara ulaşmıştır.

Hiyerarşik regresyon analizinin son aşamasında ahlaki bozulma algısı ve kurumsal sosyal sorumluluk algısı değişkenlerinin etkileşimini gösteren etkileşim faktörü analize dahil edilmiştir. Oluşturulan denklemin istatistiki olarak anlamlı olduğu ve içsel motivasyondaki değişimin yaklaşık \%55'ini açıkladığı görülmektedir. Etkileşim faktörünü içeren bu denklemin açıklama gücü bir önceki denklemin açıklama gücünden anlamlı düzeyde yüksektir $\left(\Delta \mathrm{R}^{2}=0,044\right.$ 
ve $\mathrm{p}<0,05)$. En kapsamlı model olan bu nihai modelde cinsiyet değişkeninin katsayısı istatistiksel açıdan anlamlı değilken; idari görev, kurumsal sosyal sorumluluk algısı, ahlaki bozulma algısı ve etkileşim faktörünün katsayısı anlamlıdır. Bu sonuçlara göre çalışanın idari görevde bulunması bu çalışmada ele alınan diğer değişkenlerle birlikte dikkat alındığında dahi onun içsel motivasyonunu artırmaktadır. Önceki modellerde olduğu gibi bu modelde de çalışan bulunduğu işletmenin sosyal sorumluluk faaliyeti yürüttüğüne inanırsa içsel motivasyonu da güçlenmektedir. Bunun aksine, yine önceki modellerde olduğu gibi çalışanın ahlaki bozulma algısı arttıkça içsel motivasyonu düşmektedir. Etkileşim faktörünün katsayısının pozitif ve istatistiksel açıdan anlamlı olması sebebiyle çalışanın ahlaki bozulma algısı arttıkça kurumsal sosyal sorumluluk algısının içsel motivasyon düzeyi üzerindeki etkisini güçleneceğini öne süren $\mathrm{H}_{3}$ hipotezi kabul edilmiştir. Bu sonuç şöyle yorumlanabilir: çalışan bulunduğu işletmenin etik dışı tutum ve davranışların yaygınlaştığı bir iş ortamında faaliyette bulunmasına rağmen çalışanları, müşterileri, tedarikçileri ve toplum gibi çeşitli paydaşları için değer yaratacak faaliyetleri yerine getirdiğini düşündüğünde içsel motivasyonu artmaktadır. Yani ahlaki bozulmanın hissedildiği bir ortamda kurumsal sosyal sorumluluk faaliyetlerinin çalışanların içsel motivasyonunu daha fazla olumlu yönde etkilediği söylenebilir.

$\mathrm{Bu}$ çalışmanın sonuçları işletmelerin gerçekleştirdiği sosyal sorumluluk faaliyetlerinin en önemli paydaşlarından biri olan çalışanlarının içsel motivasyonlarını artırdığını ortaya koymaktadır. Çalışanın işine bağlanmasına ve yüksek performans sergilemesine zemin hazırlayan içsel motivasyon olgusunun anlaşılmasında örgütlerin gönüllülük esasıyla yürüttügü bu tür faaliyetlerin etkisinin daha kapsamlı olarak incelenmesi yararlı olacaktır. Öte yandan çalışanların iş hayatında etik dışı uygulamaların arttığını düşünmesi durumunda içsel motivasyonlarının zayıfladığı ortaya çıkmıştır. İş hayatına ilişkin genel ahlaki bozulma algısı bir işletmenin kontrolü dışında olduğundan bu algıyı etkilemek için tek bir işletmenin yapabileceği pek bir şey yoktur. Dolayısıyla işletme yöneticileri bu olumsuz etkiyi bertaraf etmek için çalışanlarının içsel motivasyonlarını artırmaya yönelik çeşitli girişimlerde bulunabilir. Örneğin işin yapısının ve özelliklerinin çalışanların tüm becerilerini ve potansiyelini ortaya çıkaracak şekilde düzenlenmesi önerilebilir. Bu çalışmada ahlaki bozulma algısının yüksek olması durumunda kurumsal sosyal sorumluluk faaliyetlerinin içsel motivasyonu daha fazla güçlendirdiği ortaya çıkmıştır. Bu sonuç etik dışı uygulamaların yaygınlaştığı bir ekonomide toplumsal katkı sağlayan bu tür faaliyetlerin çalışanların işlerine bakışını ve motivasyonunu olumlu yönde etkilediğine, bunun da bu tür faaliyetleri gerçekleştiren işletmelere yüksek performans olarak geri döneceğine işaret etmektedir.

Her çalışma gibi bu çalışmanın da birtakım sınırlılıkları mevcuttur. Birincisi, önceden hazırlanmış soru formuna bağlı kalarak nicel (kantitatif) araştırma yaklaşımı benimsenmiştir. Kurumsal sosyal sorumluluk, ahlaki bozulma, içsel motivasyon gibi kavramları içeren araştırmalarda nicel yöntemin yanında nitel (kalitatif) yönteme de yer vermek yararlı olabilir; çünkü söz konusu kavramların anlamı, içeriği ve ölçümü konusunda nitel yaklaşımla elde edilecek bilgilerin önemli katkıları olacaktır. Dolayısıyla gelecekteki çalışmalarda nicel ve nitel araştırma yöntemlerinin birlikte kullanılması literatüre benzersiz bir katkı sunabilir. İkinci olarak, çalışanlardan birincil veri toplamanın zorluğu ve yüksek maliyetinden dolayı bu çalışmanın örneklemi sınırlı tutulmuş olup, alan araştırması yalnızca bir şehirdeki hastane çalışanları üzerinde yürütülmüştür. Örneklem büyüklüğünü artırarak farklı bölge ve şehirlerde bulunan hastane çalışanları üzerinde araştırma yapmak yararlı olabilir. Üçüncü olarak, araştırma yalnızca sağlık sektöründe gerçekleştirilmiş olup hastane çalışanlarından veri toplanmıştır. Gelecekteki çalışmaların farklı sektörlerde ve alanlarda yapılması yararlı olacaktır. Son olarak, gelecekteki çalışmalarda çeşitli bireysel ve örgütsel değişkenlerin araştırma modeline eklenmesi ele alınan kavramlar arasındaki ilişkileri daha iyi açıklamaya yardımcı olacaktır. 
Charyyev ve Karabey -Geçiş Ekonomilerinde Kurumsal Sosyal Sorumluluk, Ahlaki Bozulma ve İcsel Motivasyon Arasındaki Ilişkiler

\section{Araștırma ve Yayın Etiği Beyanı}

$\mathrm{Bu}$ çalışma bilimsel araştırma ve yayın etiği kurallarına uygun olarak hazırlanmıştır. Etik kurul onayı alınmıştır (Atatürk Üniversitesi Sosyal ve Beşerî Bilimler Etik Kurul Başkanlığı'nın 19.03.2020 tarih ve 88656144-000-E.2000088458 sayılı Onay Belgesi ile).

\section{Yazarların Makaleye Katkı Oranları}

Çalışmanın tüm kısımlarında her iki yazarın da katkısı olmuştur.

\section{Çıkar Beyanı}

Yazarlar açısından ya da üçüncü taraflar açısından çalışmadan kaynaklı çıkar çatışması bulunmamaktadır. 


\section{KAYNAKÇA}

Apressyan, R. G. (1997). Business ethics in Russia. Journal of Business Ethics, 16(14), 1561-1570.

Argon, T. \& Ertürk, R. (2013). İlköğretim okulu öğretmenlerinin içsel motivasyonları ve örgütsel kimliğe yönelik alg1ları. Kuram ve Uygulamada Eğitim Yönetimi, 19 (2), 159-179.

Aupperle, K. E., Carrol, A. B., \& Hatfield, J. D. (1985). An empirical examination of the relationship between corporate social responsibility and profitability. Academy of Management Journal, 28(2), 446-463.

Basu, K., \& Palazzo, G. (2008). Corporate social responsibility: a process model of sensemaking. Academy of Management Review, 33(1), 122-136.

Brammer, S. J., \& Pavelin, S. (2006). Corporate reputation and social performance: the importance of fit. Journal of Management Studies, 43(3), 435-455.

Brief A. P., \& Aldag, R. J. (1976). The instrinsic-extrinsic dichotomy: toward conceptual clarity. Academy of Management Review, 2 (3), 496-500.

Carroll, B. A. (1979). The pyramid of corporate social responsibility: toward the moral management of organizational stakeholders. Business Horizons, 4 (4), 39-48.

Carroll, A. B. (2004). Managing ethically with global stakeholders: a present and future challenge. Academy of Management Executive, 18 (2), 114-120.

Creative Research Systems. [Çevrim-içi: https://www.surveysystem.com/sscalc.htm]. Erişim Tarihi: 20 Haziran 2020.

Crowther, D. \& Capaldi, N. (2008). The Ashgate research companion to corporate social responsibility. Great Britain: MPG Books Ltd.

Çalışkan, O. \& Ünüsan, Ç. (2011). Otel çalışanlarının kurumsal sosyal sorumluluk algısının iş tatmini ve işte kalma niyetine etkisi. Turizm Araştırmaları Dergisi, 22 (2), 154-166.

Demir, S. \& Karakuş, M. (2015). The relationship between ethical climate and trust and motivation levels of teachers and students. Kuram ve Uygulamada Ĕ̈itim Yönetimi, 21 (2), 183-212.

Durkheim, E. (1966). The rules of sociological method. New York: Free Press.

Dünya Bankası Türkmenistan Raporu [Çevrim-içi: https://www.worldbank.org/en/country/turkmenistan]. Erişim Tarihi: 01.01.2021.

Ermongkonchai, P. (2010). Understanding reasons for employee unethical conduct in Thai organizations: a qualitative inquiry. Contemporary Management Research, 6 (2), 125-140.

Eyidiker, U. (2020). Geçiş Ekonomisi Kavramı ve Bir Geçiş Ekonomisi Örneği: Türkmenistan. Sosyal Bilimler Metinleri, 2020 (01), 13-35.

Feng, T., Wang, D. \& Bullet, A. (2016). Linking ethical leadership with firm performance: a multi-dimensional perspective. Journal of Business Ethics, 145(1), 95-109.

Field, A. (2009). Discovering statistics using SPSS. UK: Sage Publications.

Fombrun, C. J., \& Shanley, M. (1990). What's in a name? reputation building and corporate strategy. Academy of Management Journal, 33(2), 233-258.

Forsgren, A., \& Haskell, L. (2015). The impact of corporate social responsibility on intrinsic and extrinsic employee motivation: a mixed-method study of Sodexo. Degree Project, Umea School of Business and Economics, Sweden.

Fulop, G., Hisrich, R., \& Szegedi, K. (2000). Business ethics and social responsibility in transitional economies. Journal of Management Development, 19(1), 5-31.

Glinkina, S. P., Grigoriev, A., \& Yakobidze, V. (2001). Crime and corruption. In L. R. Klein \& M. Pomer (Eds.), The new Russia: transition gone awry (pp. 233-250). Stanford, CA: Stanford University Press.

Hopkins, M. (2007). Corporate social responsibility and international development: is business the solution? Great Britain: Earthscan Press.

Hough,C., Green, K. \& Plumlee, G. (2016). Impact of ethics environment and organizational trust on employee engagement. Journal of Legal, Ethical and Regulatory Issues, 18, 45-62.

Huang, X., \& Watson, L. (2015). Corporate social responsibility research in accounting. Journal of Accounting Literature, 34, 1-16. 
Jamali, D., Mirshak, R. (2007). Corporate social responsibility (CRS): theory and practice in a developing country context. Journal of Business Ethics, 72, 243-262.

James, W. (1890). The principles of psychology. New York: Holt.

Kim, C. H. \& Scullion, H. (2013). The effect of corporate social responsibility (CSR) on employee motivation: a cross-national study. Economics and Business Review, 13(2), 5-30.

Kuvaas, B. (2006). Work performance, affective commitment, and work motivation: the roles of pay administration and pay level. Journal of Organizational Behavior, 27(3), 365-385.

Kuvaas, B., \& Dysvik, A. (2009). Perceived investment in employee development, intrinsic motivation, and work performance. Human Resource Management Journal, 19(3), 217-236.

Lantos, G. P. (2002). The ethicality of altruistic corporate social responsibility. The Journal of Consumer Marketing, $19(2 / 3), 205-208$.

Lindgreen, A., Swaen, V., \& Johnston, W. J. (2009). Corporate social responsibility: an empirical investigation of US organizations. Journal of Business Ethics, 85(2), 303-323.

Lu, C. J., Shih, Y. Y. \& Wang, S. T. (2016, 6-8 July). The effect of corporate social responsibility initiatives on internal employee motivation and organizational identification, 10th International Conference on Innovative Mobile and Internet Services in Ubiquitous Computing (IMIS), Fukuoka, Japan, doi: 10.1109/IMIS.2016.85.

Luo, M., Huang, W., \& Najjar, L. (2007). The relationship between perceptions of a Chinese high school's ethical climate and students' school performance. Journal of Moral Education, 36(1), 93-111.

Luo, Y. (2008). A strategic analysis of product recalls: the role of moral degradation and organizational control. Management and Organization Review, 4(2), 183-196.

Martin, K. D., Cullen, J. B., Johnson J. L., \& Parboteeah, K. P. (2007). Deciding to bribe: a cross-level analysis of firm and home country influences on bribery activity. Academy of Management Journal, 50(6), 1401-1422.

McWilliams, A., \& Siegel, D. S. (2001). Corporate social responsibility: a theory of the firm perspective. Academy of Management Review, 26(1), 117-127.

Menon, S., Kahn, B. E. (2003). Corporate sponsorships of philanthropic activities: when do they impact perception of sponsor brand? Journal of Consumer Psychology, 13(3), 316327.

Messner, S. F., \& Rosenfeld, R. (2001). Crime and the American dream. Belmont, CA: Wadsworth.

Mottaz J. C. (1985). The relative importance of intrinsic and extrinsic rewards as determinants of work satisfaction. The Sociological Quarterly, 26 (3), 365-385.

Muller, A., \& Kolk, A. (2010). Extrinsic and intrinsic drivers of corporate social performance: evidence from foreign and domestic firms in Mexico. Journal of Management Studies, 47(1), 1-26.

Murphy, P. K., \& Alexander, P. A. (2000). A motivated exploration of motivation terminology. Contemporary Education Psychology, 25(1), 3-53.

Nanderam, D.R. (2010). Corporate social responsibility and employee engagement: an exploratory case study. Unpublished doctoral dissertation, Capella University, USA.

North, D. C. (1990). Institutions, institutional change and economic performance. Cambridge, MA: Harvard University Press.

Skudiene, V., Auruskeviciene, V. (2012). The contribution of corporate social responsibility to internal employee motivation. Baltic Journal of Management, 7 (1), 49-67.

Sökmen, A. \& Ekmekçioğlu, E. B. (2013). The effect of managers' ethical behaviour on boundary spanning role employees' motivation and job satisfaction: a research in Adana. Işletme Araştırmaları Dergisi, 5 (4), 87-104.

Strong, K. C., Ringer, R. C., \& Taylor, S. A. (2001). The ruled of stakeholder satisfaction (timeliness, honesty, empathy). Journal of Business Ethics, 32(3), 219-230.

Tiggeman, T.B. (2018). Accountants' perspectives on corporate social responsibility and the environment: a correlational study. Unpublished doctoral dissertation, Northcentral University School of Business and Technology Management, USA.

Tyagi, P. K. (1982). Perceived organizational climate and the process of salesperson motivation. Journal of Marketing Research, 19, 240-254. 
Valentine, S., Fleischman, G. (2008). Ethics programs, perceived corporate social responsibility and job satisfaction. Journal of Business Ethics, 77 (2), 159-172.

Visser, W., Matten, D., Pohl, M. \& Tolhurst, N. (2010). The A to Z of Corporate Social Responsibility, $2^{\text {nd }}$ Revised and Updated Edition, UK: John Wiley \& Sons Ltd.

Yurdadoğ, V.; Akça, H. \& Ünlükaplan, İ. (2016). Geçişin 25. Yılında Orta Asya Türk Cumhuriyetlerinde Dönüşüm Sürecini Özelleştirme ve İktisadi Özgürlükler Açısından Değerlendirme. Eurasian Academy of Sciences Eurasian Business \& Economics Journal, (4), 100-121.

Wentzel, K. R. (1998). Social relationships and motivation in middle school: the role of parents, teachers, peers. Journal of Educational Psychology, 90(2), 202-209.

Wong, S. C. \& Li, J. S. (2015). Will hotel employees' perception of unethical managerial behavior affect their job satisfaction? a study of Chinese hotel employees in China. International Journal of Contemporary Hospitality Management, 27(5), 853-877.

Zhang, R., \& Rezaa, Z. (2009). Do credible firms perform better in emerging markets? Journal of Business Ethics, 90(2), 221-237.

Zheng, Q., Luo, Y., Wang, S. (2014). Moral degradation, business ethics, and corporate social responsibility in a transitional economy. Journal of Business Ethics, 120, 405-421. 


\section{Extended Summary}

\section{The Relationships among Corporate Social Responsibility, Moral Degradation and Intrinsic Motivation in Transition Economies}

The aim of this study is to examine the relationship between employees' corporate social responsibility (CSR) perception and intrinsic motivation and investigate whether moral degradation perception has a moderator role in this relationship. First literature review was conducted to explore the relationships among aforementioned variables and accordingly the following hypotheses have been formulated:

$\mathrm{H}_{1}$ : Employee's CSR perception has a positive impact on their intrinsic motivation.

$\mathrm{H}_{2}$ : Employee's moral degradation perception has a negative impact on their intrinsic motivation.

$\mathrm{H}_{3}$ : The impact of CSR perception on intrinsic motivation gets stronger as employee's moral degradation perception increases.

Question forms were used to collect data for the survey. To create the question form, previous studies were scanned and measures having high reliability and validity were selected. The question form began with questions about demographic variables. Then intrinsic motivation was measured with 6 items developed by Kuvaas (2006) and improved by Kuvaas and Dysvik (2009). In order to measure employee's moral degradation perception about working life, 4 items developed by Zheng et al. (2014) were used. Participants were asked to reply 4 questions twice considering business environment both today and 10 years ago. The extent of the difference implies moral degradation perception. While internal CSR perception was measured with 6 items of Lindgreen et al. (2009), external CSR perception was measured with 4 items of Menon and Kahn (2003). Except for demographic variables, all scales were 5-point Likert type (1strongly disagree....3-neither agree nor disagree.......5-strongly agree).

The population of the study consists of 193 employees of a hospital operating in Turkmenabat province of Turkmenistan. While Turkmenistan was a part of Soviet Union in the past, it is considered as a transitional economy today. The sample size to be selected with a $95 \%$ confidence level and 5\% margin of error was calculated as 129 (https://www.surveysystem.com/sscalc.htm). Question forms were distributed to 129 employees selected with simple random sampling method and all of them were collected back being suitable for data analysis. The data were analysed with IBM SPSS 25.0 software. First, exploratory factor analysis was conducted on each variable and the structural components were revealed. Second, correlation analysis was conducted in order to examine the relationships among variables. Third, regression analyses were conducted to test the hypotheses.

The results of exploratory factor analyses show that CSR perception, intrinsic motivation and moral degradation perception are all unidimensional. According to correlation analyses, there is a strong and positive relationship between CSR perception and intrinsic motivation $(\mathrm{r}=$ $0,679)$. There is a moderate and negative relationship between intrinsic motivation and moral degradation perception $(\mathrm{r}=-0,378)$. Moreover, there is a negative and weak relationship between CSR perception and moral degradation perception $(r=-0,297)$.

After correlation analyses, 4-step hierarchical regression analysis was conducted to test hypotheses. The standardized values ( $\mathrm{Z}$ values) of independent variables, namely CSR perception and moral degradation perception, were used to prevent multicollinearity in the regression equations that include moderator variable. Besides $\mathrm{Z}$ values of aforementioned variables were multiplied to estimate the moderator variable. The results of hierarchical regression analysis are as follows: 
$\mathrm{H}_{1}$, which states that CSR perception has a positive impact on intrinsic motivation, was accepted. $\mathrm{H}_{2}$, which states that moral degradation perception has a negative impact on intrinsic motivation, was accepted. $\mathrm{H}_{3}$, which states that the impact of CSR perception on intrinsic motivation gets stronger as employee's moral degradation perception increases, was accepted. These findings highlight that employees feel higher intrinsic motivation when they believe their firms conduct corporate social responsibility activities. They also feel lower intrinsic motivation when they think moral and ethical values in business life fade in time. When a firm conducts social responsibility activities in a business environment which is perceived morally corrupt, the employees of this firm will have high intrinsic motivation since they believe their organization creates value for various stakeholders. In other words, in a morally corrupt business environment CSR activities increase intrinsic motivation of employees more strongly.

As with all studies, this study has some limitations. First, a quantitative approach based on question forms was adopted. Future studies should also adopt qualitative approaches due to the fact that data obtained from a qualitative study could make a significant contribution to the conceptualization, content and measurement of corporate social responsibility, moral degradation and intrinsic motivation. Thus, the use of mixed approach in future studies could be very beneficial. Second, because of the inconvenience and high cost of gathering primary data from employees, the sample of the study includes employees from one hospital in a province. Future studies should increase the sample size by including employees from different hospitals in different regions and cities. Third, since this research was only conducted on health sector, future research should be conducted on various industries in order to gain a broader perspective. Last, the addition of some individual and organizational variables to the research model should help clarify the relationships among the variables in this study. 